\section{Nei takk, ikke bra nok!}

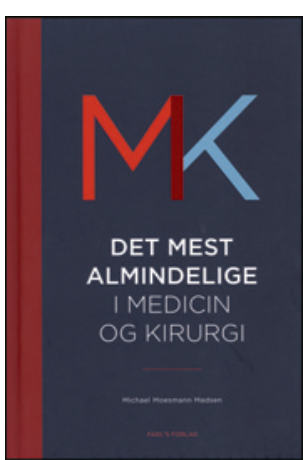

Michael Moesmann Madsen

Det mest almindelige i medicin og kirurgi

271 s, tab, ill. København: FADL's Forlag.

2016. Pris DKK 400

ISBN 978-87-7749-855-8

Boken er tiltenkt medisinstudenter som skal forberede seg til eksamen, og nyutdannede leger med lite klinisk erfaring og behov for raskt å få oversikt over de mest vanlige tilstandene $\mathrm{i}$ indremedisin og kirurgi.

Forfatteren mener at hans bok er nyttig for sortering, men samtidig medgir han at den er betydelig forenklet. Boken bygger på personlige erfaringer og forfatterens egen studieteknikk mens han studerte medisin. Den er innbundet og ikke i lommeformat. Innledningsvis har forfatteren et kapittel som omtaler hvordan han personlig har lært mest på kortest mulig tid om det mest vanlige, gjennom bruk av gjentatte repetisjoner og ulike huskeregler.

Boken er todelt. Den første delen omhandler det mest alminnelige i et akuttmottak, det er en problemorientert tilnærming basert på symptomer. Den andre delen omhandler de mest vanlige sykdommene hos inneliggende pasienter. Utvalget er begrenset og meget mangelfullt. Sykdom hos barn er ikke inkludert.

Språket er dansk, med innslag av engelske ord. Mange forkortelser som ikke alltid er definert, vanskeliggjør lesingen. Ellers er det mange oppramsinger av problemstillinger, dels ledsaget av tabeller med beskrivelse av tilstand i form av diagnose eller symptomer, behandling og behov for kontroll.

Organiseringen av boken virker uryddig og til dels tilfeldig - og er etter min oppfatning ikke særlig praktisk nyttig. Innholdsregisteret er heller ikke optimalt, vekttap er for eksempel omtalt med 20 forskjellige angivelser, tretthet 23, akuttmottagelse er oppgitt 17 ganger og hemoglobin 15 ganger, mens anemi er uteglemt. Grenblokk er rubrisert under $\mathrm{N}$ fordi det er «nytilkommet» og ikke under $\mathrm{G}$.

Det finnes en rekke gode, praktiske norske metodebøker innen både indremedisin, akuttmedisin og kirurgi, i lommeformat, på nett eller som app, og de omtaler både akutte og kroniske tilstander. Denne boken var lite inspirerende lesning, dårlig som oppslagsverk, og med lite kritisk vurdering av utvalget av tilstander.

Jeg kan dessverre ikke anbefale den verken for medisinstudenter eller leger.

\section{Ingrid Os}

Prodekan for medisinstudiet, Det medisinske fakultet Universitetet i Oslo

\section{Nyttig om sosialmedisin og rehabilitering}

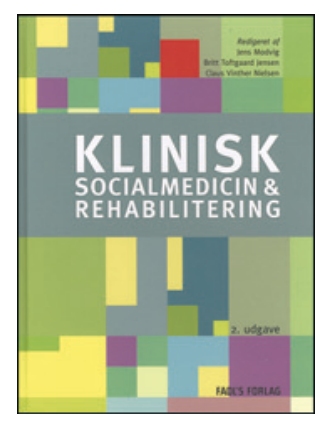

\author{
Jens Modvig, Britt Toftgaard Jensen, \\ Claus Vinter Nielsen, red. \\ Klinisk socialmedicin \& rehabilitering \\ 2. utg. 311 s, tab, ill. København: FADL's \\ Forlag, 2016. Pris DKK 450 \\ ISBN 978-87-7749-851-0
}

Dette er en dansk lærebok for studenter i medisin og folkehelse og for leger med sosialmedisinske oppgaver. Klinisk sosialmedisin beskrives som et fagområde som ikke kun er avhengig av leger, men også av en rekke andre profesjoner innen helse- og sosialtjenesten. Fagets formål er å bevare og utvikle kunnskap om hvordan optimal funksjonsevne kan oppnås og ivaretas til tross for sykdom og kroniske plager. Også rehabilitering er i stor grad av tverrfaglig karakter og dermed avhengig av en koordinert, helhetlig og vitenskapelig basert innsats med mange yrkesgrupper involvert.

Boken er lettlest, og de 22 kapitlene er relativt korte. Teksten er gitt en fargerik og variert layout som gjør den attraktiv å lese. Hvert kapittel innledes med et sammendrag, og den videre teksten inneholder pasienteksempler, tabeller, figurer og fakta i bokser med blant annet lover og regler. Et fagstoff som av noen kan oppleves å være regelorientert, er dermed gjort lettere tilgjengelig for klinikere og annet helsepersonell.

I denne læreboken beskriver man «verktøy og metoder» som gjør leger i stand til å vurdere om en pasient har behov for sosialmedisinsk bistand og rehabilitering, og hvilke tiltak som kan settes inn, i tillegg til medisinsk diagnostikk og behandling. Målet er å styrke fysisk, psykisk og sosial funksjonsevne som kan bidra til økt livskvalitet og arbeidsevne. Vanligvis trengs det samarbeid mellom en rekke profesjoner i ulike statlige, kommunale og private instanser for å oppnå et vellykket resultat.

Forfatterne har ulik bakgrunn og kompetanse. De gir en bred og faglig solid innføring i faget sosialmedisin, som er ment å skulle hjelpe de mest vanskeligstilte i samfunnet. Én av sosialmedisinens oppgaver er funksjonsvurdering av de som er sykmeldt og trenger arbeidsrettet rehabilitering eller utredning for eventuell uføretrygd. Forfatterne beskriver metoder for funksjonsevnevurdering, den kliniske sosialmedisinske journalen, tverrfaglig samarbeid og koordinering mellom helsevesen, sosialetat og andre instanser. Både barn, unge, eldre og funksjonshemmede er viet egne kapitler. Det samme gjelder for eksempel sårbare gravide, hjemløse, innvandrere og flyktninger, i tillegg til personer med alkohol- og rusproblemer, og ofre for tortur, vold og seksualforbrytelser.

Boken er nyttig for studenter, men kan også være av interesse for allmennleger, Nav-leger, bedriftsleger, rehabiliteringsleger, psykiatere og samfunnsmedisinere. En ulempe er at den er skrevet for danske forhold basert på dansk lovverk. Dette har likevel mange paralleller til norsk lovgivning og de metodene som kreves for å møte sosialmedisinske utfordringer i vårt eget land. Denne bredt anlagte boken understreker behovet for en ny og oppdatert lærebok også her i landet.

Gunnar Tellnes

Professor og spesialist i samfunnsmedisin, Institutt for helse og samfunn Universitetet i Oslo 